\title{
Otita medie acută în practica pediatrică: update
}

\author{
Doina Anca Pleşca \\ Universitatea de Medicină şi Farmacie „Carol Davila“, Bucureşti, România
}

\begin{abstract}
REZUMAT
Otita medie acută (OMA) este una dintre cele mai frecvente infecții din copilărie. Este considerată cauza principală a prescrierii antibioticelor în pediatrie. Medicii au tendința de a supradiagnostica această boală, ducând la o prescripție inutilă de antibiotice, care expune copilul la reacții adverse nedorite, în principal diaree.

Diagnosticul se bazează în mod obișnuit pe simptome și pe examenul otoscopic. Un diagnostic de OMA trebuie luat în considerare la orice copil mic care prezintă iritabilitate, letargie, otoree și febră, cu sau fără durere localizată la ureche.

Distincția dintre OMA și otita medie cu efuziune (OME) este importantă. OME este mai frecventă decât OMA.

Tratamentul primar are drept scop reducerea durerii. Simptomele în OMA izolate, unilaterale, se rezolvă de obicei după 2 zile fără tratament antibiotic. Trebuie luată întotdeauna în considerare posibilitatea de sepsis la un copil bolnav cu febră.
\end{abstract}

Cuvinte cheie: otită medie acută, copil, infecții, antiinflamator, analgezic

\section{INTRODUCERE}

Infecţiile tractului respirator (ITR) reprezintă una dintre principalele cauze de morbiditate și mortalitate în întreagă lume atât la copii, cât şi la adulţi $(1,2)$. În ţările dezvoltate, aproximativ 50\% dintre consultaţii sunt reprezentate de bolile aparatului respirator. ITR sunt produse de agenţi etiologici diverşi (viruşi, bacterii, fungi, protozoare etc.) care pot să afecteze căile respiratorii superioare şi/sau inferioare. De cele mai multe ori, evoluţia acestor infecţii este benignă, autolimitată şi, implicit, uşor de tratat. Există situaţii în care evoluţia clinică este severă (pneumonia acută comunitară, bronşiolita acută, bronșita etc.) și poate să fie urmată de constituirea unor leziuni pulmonare sechelare importante, toate acestea impunând o abordare terapeutică susţinută şi de lungă durată.

De cele mai multe ori, ITR au un caracter recurent, astfel că, în decursul unui an, pot să apară mai multe episoade de îmbolnăviri. Frecvenţa infecţiilor respiratorii variază în funcţie de vârsta pacientului. În primii ani (0-6 ani), infecţiile acute respiratorii superioare au o frecvenţă de 6-8 episoade/an. În cazul în care copiii frecventează o colectivitate (creşă, grădiniţă, şcoală etc.), numărul acestor episoade poate să crească. În contrast, infecţiile acute respiratorii inferioare sunt mai rare, mai severe, impun de cele mai multe ori spi- talizare şi, implicit, necesită costuri mari pentru îngrijiri medicale. Se estimează că, în ţările dezvoltate, aproximativ $6 \%$ dintre copiii cu vârsta sub 6 ani prezintă ITR cu caracter recurent. Structura pe vârstă a ITR recurente care apar în copilărie arată că $25 \%$ dintre episoade se înregistrează la copii sub vârsta de un an şi $18 \%$ apar la copii cu vârste cuprinse între 1 şi 4 ani (3).

După infecţiile căilor respiratorii superioare, otita medie acută (OMA) (otita acută supurată) este cea mai frecventă afecţiune pentru care se solicită asistenţă medicală (Philip Fierman, 2003). În plus, este considerată cea mai frecventă infecţie bacteriană la sugar şi la copilul mic, având un vârf al incidenţei între 6 şi 11 luni.

Se estimează că $80 \%$ dintre copii vor avea un episod de OMA în primii 3 ani şi 30\% vor avea 2 sau mai multe episoade, în timp ce $25 \%$ dintre sugari vor prezenta peste 3 episoade/an.

Otita medie acută constă în inflamaţia acută, de obicei purulentă, a urechii medii, produsă un agent patogen infecţios (bacterii, virusuri, infecţii viro-bacteriene), care pătrunde prin trompa lui Eustachio la nivelul urechii medii. Afecţiunea debutează brusc prin prezenţa unor semne şi simptome ale inflamaţiei, cum ar fi otalgia şi febra. 


\section{FACTORI FAVORIZANȚI}

Cei mai importanţi factori favorizanţi sunt:

- Susceptibilitatea crescută la infecţii acute respiratorii (ITR) (5). Unul din 3 copii cu ITR superioare va dezvolta OMA şi $94 \%$ dintre ITR preced OMA (7);

- Particularităţile anatomice ale trompei lui Eustachio la sugar şi la copilul mic (scurtă, orizontalizată, largă, tonus muscular redus, elemente care predispun la obstrucţie) $(5,8)$;

- Particularităţi anatomice ale masivului cranian;

- Reflux gastro-esofagian;

- Alimentarea sugarului în poziţia culcat;

- Utilizarea suzetei $(6,8)$;

- Fumatul pasiv $(6,8)$;

- Frecventarea colectivităţii $(6,9)$;

- Imaturitate imună (sinteză redusă de Ac)

În tabelul 1 sunt ilustraţi factorii favorizanţi responsabili de producerea otitei medii acute (17).

TABELUL 1. Factori favorizanți în OMA

\begin{tabular}{|l|}
\hline Factori favorizanți \\
\hline Infecțioși: rinofaringite acute, rinosinuzite acute sau cronice \\
\hline $\begin{array}{l}\text { Mecanici și inflamatorii: vegetații adenoide, tumori benigne } \\
\text { sau maligne ale foselor nazale, deviația de sept nazal }\end{array}$ \\
\hline Mecanici: palatoschizis \\
\hline $\begin{array}{l}\text { Traumatici: adenoidectomia, tamponamentul anterior și } \\
\text { posterior al foselor nazale, perforațiile timpanice }\end{array}$ \\
\hline $\begin{array}{l}\text { Generali: boli infecto-contagioase (gripă, rujeolă, rubeolă, } \\
\text { varicelă, scarlatină), alergia, pneumonia/bronhopneumonia }\end{array}$ \\
\hline $\begin{array}{l}\text { Alții: frigul, umezeala, schimbările bruște de temperatură, } \\
\text { nealăptatul la sân }\end{array}$ \\
\hline
\end{tabular}

\section{ETIOLOGIE}

Otita acută medie (supurată) este definită ca o reacţie inflamatorie care apare la nivelul urechii medii secundar unei infecţii acute respiratorii superioare. La copii, particularităţile anatomice ale trompei lui Eustachio favorizează apariţia mai frecventă a infecţiei. Etiologia OMA poate să fie variată: bacteriană, virală sau mixtă (viro-bacteriană).

În tabelul 2 este ilustrată cea mai frecventă etiologie regăsită în $\operatorname{OMA}(9,11,14)$.

TABELUL 2. Etiologia bacteriană în OMA (după Institut National d'excellence en santé et en services sociaux, Quebec, 2016)

\begin{tabular}{|l|}
\hline Cele mai frecvente etiologii bacteriene \\
\hline Streptococcus pneumoniae (40-50\%) \\
\hline Haemophilus influenzae (30-40\%) \\
\hline Moraxella catarrhalis (10-20\%) \\
\hline Staphylococcus pyogenes și Staphylococcus aureus (10-20\%) \\
\hline Streptococcus pyogenes \\
\hline
\end{tabular}

\section{CRITERII DE DIAGNOSTIC}

Elementele definitorii pentru diagnosticul pozitiv de otită medie acută (OMA) sunt următoarele $(8,11)$ :

- Debut acut (febră, alterarea stării generale, refuz alimentar etc.);

- Prezenţa exsudatului la nivelul urechii medii;

- Semne şi simptome ale inflamaţiei urechii medii (otalgie, eritem al membranei timpanale etc.);

Semnele şi simptomele cel mai frecvent regăsite la copilul cu OMA sunt ilustrate şi în tabelul 3:

- Febră înaltă, letargie, iritabilitate, anorexie

- Plâns, ţipete neconsolate;

- Otalgie severă şi pulsatilă debutată brusc;

- Otoree, cefalee, semne/simptome de infecţie înaltă respiratorie;

- La copilul mai mare pot să apară vertij, hipoacuzie.

TABELUL 3. Semne şi simptome asociate OMA

\begin{tabular}{|c|c|c|}
\hline $\begin{array}{l}\text { Semne şi simptome } \\
\text { localizate la nivelul } \\
\text { extremității cefalice }\end{array}$ & $\begin{array}{l}\text { Semne şi simptome } \\
\text { generale }\end{array}$ & Alte semne \\
\hline $\begin{array}{l}\text { Otalgie } \\
\text { Otoree } \\
\text { Cefalee } \\
\text { Semne /simptome } \\
\text { de IACRS }\end{array}$ & $\begin{array}{l}\text { Febră } \\
\text { Iritabilitate } \\
\text { Letargie } \\
\text { Anorexie } \\
\text { Greață/vărsături } \\
\text { Diaree }\end{array}$ & $\begin{array}{l}\text { Vertij } \\
\text { Hipoacuzie }\end{array}$ \\
\hline
\end{tabular}

\section{Diagnostic pozitiv}

Diagnostic clinic de OMA presupune prezenţa obligatorie a următoarelor elemente clinice $(9,14)$ :

- debut acut, în primele 24-48 ore;

- timpan roşu şi bombat la examenul otoscopic;

- acumulare lichidiană la nivelul urechii medii.

Congestia izolată a timpanului NU este sugestivă pentru OMA. Aceasta poate să fie produsă de diferite alte cauze precum: febră, plâns, traumă, infecţii acute respiratorii superioare.

Cea mai importantă procedură de confirmare OMA este examenul otoscopic $(8,10,14,17)$. La examenul otoscopic se pot decela alterări ale timpanului cu modificări histologice particulare diferitelor etape evolutive:

- faza congestivă (17): timpanul este hiperemic în jurul mânerului ciocanului, apoi pe întreg cuprinsul pars tensa;

- faza exsudativă (17): timpanul este mat, cu conul luminos Politzer modificat sau dispărut, uneori prin transparenţa timpanului se poate vedea un nivel de lichid sau bule de aer; mobilitatea timpanului este redusă. După apariţia supuraţiei la nivelul urechii medii, timpanul devine intens congestiv, bombat, îngroşat, cu pierderea reperelor clasice anatomice. În evo- 
luţie, timpanul perforează cel mai des la nivelul cadranelor inferioare, iar conductul auditiv extern este umplut iniţial cu secreţii seroase, apoi mucopurulente. După aspirarea secreţilor din conduct, se poate observa perforaţia timpanului;

Alte proceduri suplimentare de confirmare a diagnosticului pozitiv sunt: examen otomicroscopic, endoscopie nazo-faringiană, examenul microbiologic al secreţilor recoltate, radiografiile în incidenţă Schüller, timpanograma (10) etc.

\section{Diagnostic diferențial}

În faţa unui copil cu semne şi simptome de OMA, se impune efectuarea unui diagnostic diferenţial. Cele mai frecvente entităţi clinice care sunt luate în discuţie sunt:

1. Otita externă, care este o infecţie a canalului auditiv extern.

2. Otita medie seroasă reprezintă o entitate clinică frecvent regăsită în patologia pediatrică. Se caracterizează prin acumularea de lichid abacterian la nivelul urechii medii. În absenţa inflamaţiei, cel mai frecvent este asimptomatică. Poate să apară în contextul unei infecţii acute respiratorii care determină disfuncţia trompei lui Eustachio sau după rezoluţia unui episod de OMA (10).

3. Otita medie recurentă se defineşte ca episoade repetate de OMA ( $\geq 3$ episoade de OMA în 6 luni cu evidenţă de vindecare între episoade sau $\geq 4$ episoade de OMA în 12 luni) (9).

Până la împlinirea vârstei de 7 ani, aproximativ $40 \%$ dintre copii au $\geq 6$ episoade de OMA.

Şi alte afecţiuni cu localizare craniană pot avea un tablou clinic asemănător OMA. Dintre acestea, menţionez: otită medie cronică reacutizată, unele afecţiuni dentare, afecţiuni ale articulaţiei temporomandibulare etc.

\section{TRATAMENT}

Tratamentul OMA este complex $(6,8,9)$. Acesta constă din terapia durerii, terapia antiinfecţioasă, metode chirurgicale, la care se adaugă metode profilactice (vaccinare antipneumococică etc.).

OMA este o condiţie medicală asociată cu durere semnificativă $(9,14)$. În această situaţie, tratamentul durerii trebuie iniţiat cât mai rapid, indiferent dacă pacientul pediatric primeşte sau nu antibioterapie. Administrarea orală/intrarectală de analgezice trebuie să fie iniţiată cât mai rapid (în primele 24 ore de la debutul simptomatologiei) pentru a reduce suferinţa copilului. Medicaţia utilizată este reprezentată de analgezice/antipiretice. Dintre acestea, menţionăm: ibupro- fen $10 \mathrm{mg} / \mathrm{kgc} /$ doză (max. $400 \mathrm{mg}$ ) administrat per os la 6-8 ore şi/sau acetaminofen / paracetamol administrat la sugari după vârsta de 3 luni, în doze de $15 \mathrm{mg} /$ $\mathrm{kg} /$ doză per os, la 6 ore (15).

Atât acetaminofenul, cât şi ibuprofenul sunt eficiente în reducerea durerii în cazul copiilor cu OMA (9). Această afirmaţie se bazează pe o metaanaliză întreprinsă asupra unor trialuri randomizate şi controlate (Sjoukes et al., 2016). În aceeaşi metaanaliză, nu au fost identificate diferenţe semnificative între cele două produse în ceea ce priveşte reducerea durerii. Utilizarea combinată a celor două medicamente nu a fost superioară utilizării doar a unui singur produs (9).

Utilizarea de substanţe analgezice topice locale sub formă de picături creşte semnificativ numărul pacienţilor la care durerea s-a redus după administrare (9).

În conformitate cu ultimele ghiduri publicate (9), decongestionantele nazale şi antihistaminicele utilizate ca monoterapie sau ca terapie combinată nu au demonstrat că ameliorează simptomatologia determinată de OMA.

OMA este o infecţie autolimitată a urechii medii. Aceasta este determinată de virusuri şi/sau bacterii care pot fi uneori prezente concomitent. La majoritatea copiilor, OMA se rezolvă fără tratament antibiotic (9).

Majoritatea copiilor cu OMA unilaterală, izolată, nu necesită terapie cu antibiotice $(9,17)$.

Iniţierea antibioterapiei este recomandată tuturor copiilor care prezintă semne si simptome sistemice severe precum hipertermie, vărsături, letargie, refuz alimentar.

La următoarele categorii de pacienţi pediatrici se impune iniţierea de antibioterapie (14):

- Sugari sub 6 luni

- Copii sub 2 ani cu OMA bilaterală

- Simptomatologie care durează de peste 48 ore

- Perforaţie timpanală (otoree, vizualizarea perforaţiei timpanale)

- Copii imunodeprimaţi

În tabelul 4 sunt ilustrate abordările terapeutice în OMA, în funcţie de vârstă (14).

TABELUL 4. Recomandările terapeutice în funcție de vârstă

\begin{tabular}{|l|l|}
\hline Vârstă & Recomandări terapeutice inițiale \\
\hline$<2$ luni & $\begin{array}{l}\text { Internare obligatorie } \\
\text { Managementul durerii } \\
\text { Timpanocenteză și culturi din secreții } \\
\text { Ceftriaxon sau amoxicilină-acid clavulanic în } \\
\text { dozele standard }\end{array}$ \\
\hline Între 2 și 6 luni & $\begin{array}{l}\text { Amoxicilină-acid clavulanic în doze mari timp } \\
\text { de 10 zile }\end{array}$ \\
\hline
\end{tabular}




\begin{tabular}{|l|l|}
\hline Vârstă & Recomandări terapeutice inițiale \\
\hline Peste 6 luni & Timp de 48-72 ore, în cazul în care nu \\
& este vorba de o afecțiune severă, se va \\
& supraveghea pacientul \\
& Prima linie de tratament - amoxicilină \\
& $80-90 \mathrm{mg} / \mathrm{kg}, 7-10$ zile \\
& Managementul durerii cu analgezice \\
& Amoxicilină-acid clavulanic în prezența \\
& semnelor severe de boală sau a istoricului de \\
& utilizare anterioară de antibiotice \\
\hline
\end{tabular}

În cazul în care nu există răspuns la terapia iniţială, se recomandă următoarea abordare (tabelul 5) $(8,9$, 14,15).

TABELUL 5. Recomandări terapeutice după eşecul primei scheme de tratament

\begin{tabular}{|l|l|}
\hline Terapia inițială & $\begin{array}{l}\text { Amoxicilină } 80-90 \mathrm{mg} / \mathrm{kg} / \text { zi } \\
\text { Managementul durerii utilizând } \\
\text { analgezice }\end{array}$ \\
\hline $\begin{array}{l}\text { Dacă anterior pacientul } \\
\text { a primit antibioterapie }\end{array}$ & $\begin{array}{l}\text { Amoxicilină-acid clavulanic } 90 \mathrm{mg} / \\
\mathrm{kg} / \text { zi de amoxicilină și } 6,4 \mathrm{mg} / \mathrm{kg} / \\
\text { zi acid clavulanic, de } 2 \text { ori/zi timp de } \\
5-10 \text { zile. } \\
\text { Managementul durerii utilizând } \\
\text { analgezice }\end{array}$ \\
\hline $\begin{array}{l}\text { Lipsă de răspuns după } \\
\text { 48-72 ore utilizând } \\
\text { tratament farmacologic }\end{array}$ & $\begin{array}{l}\text { Ceftriaxon } \\
\text { Timpanocenteză } \\
\text { Managementul durerii cu analgezice }\end{array}$ \\
\hline
\end{tabular}

În cele mai multe din cazuri, otita medie acută apare din cauza infecţiei virale a tractului respirator superior, de aceea se consideră ca, timp de 24-48 de ore, să se temporizeze iniţierea tratamentului cu antibiotic. În urma studiilor întreprinse în ultimii ani, s-a observat că, la sugarii şi copiii cu vârste cuprinse între 6 luni şi 10 ani care nu au prezentat semne de boală severă (otalgie moderată/medie, febră sub $39^{\circ} \mathrm{C}$, timpan congestionat fără bombare) şi la care nu s-a iniţiat de la debutul simptomatologiei tratament antibiotic, 67\% dintre aceştia nu au mai necesitat antibioterapie $(8,14,15)$.

La copiii sub vârsta de 6 luni sau care prezintă semne de boală severă (otalgie medie/severă, febră peste $39^{\circ} \mathrm{C}$, timpan intens congestionat, fără repere anatomice), se instituie tratament antibiotic $(14,15)$. Ca variante terapeutice agreate în prezent, precizăm:

- Amoxicilină per os $80-90 \mathrm{mg} / \mathrm{kgc} / \mathrm{zi}$;

- Claritromicină, azitromicină, eritromicină per os;

- Cefalosporine: cefuroximă $(30 \mathrm{mg} / \mathrm{kgc} / \mathrm{zi})$, ceftriaxon (30-50 mg/kg/zi); cefdinir pe os (15 $\mathrm{mg} / \mathrm{kgc} / \mathrm{zi})$;

Durata tratamentului antibiotic este variabilă. Astfel, pentru copiii în primii 2 ani, terapia este de 10 zile, în timp ce, pentru copiii cu vârsta de peste 2 ani, terapia este de 7-10 zile. În caz de eşec al antibioterapiei, se intervine chirurgical (timpanotomie). În tabe- lul 6 sunt ilustrate recomandările care vizează durata antibioterapiei în funcţie de severitatea bolii şi vârsta pacientului (16).

TABELUL 6. Durata antibioterapiei în funcție de severitate şi vârsta pacientului

\begin{tabular}{|l|l|l|}
\hline & $\begin{array}{l}\text { Recomandare de } \\
\text { AB orală }\end{array}$ & Ceftriaxon \\
\hline OMA severă & $0-18$ ani 10 zile & 3 zile \\
\hline & $<2$ ani 10 zile & \\
\hline OMA uşoară/moderată & $2-5$ ani 7 zile & 3 zile \\
\hline & Peste 5 ani 7 zile & \\
\hline
\end{tabular}

Decongestionantele nazale şi antihistaminicele nu se recomandă; nu există beneficii clinice demonstrate.

Metodele chirurgicale constau din miringotomie, adenoidectomie, antrostomie / mastoidectomie.

Miringotomia $(7,10,14,17)$ se indică când nu există un răspuns la tratament antibiotic, manifestat prin persistenţa otalgiei şi a febrei după 48-72 de ore. Este o intervenţie chirurgicală în condiții de sterilitate şi se efectuează sub anestezie generală. Incizia membranei timpanice se face în cadranul antero-inferior şi trebuie sa fie paralelă cu fibrele radiare din pars tensa cu aspirarea secreţiilor. Pentru a evita cicatrizarea rapidă a inciziei, se plasează un tub aerator transtimpanal.

Adenoidectomia $(9,17)$ se indică în otita medie recurentă/recidivantă.

Antrostomia/mastoidectomia $(9,17)$ este indicată când se suspicionează prezenţa unei complicaţii (otomastoidita).

La copiii sub vârsta de 2 ani vaccinaţi antigripal, s-a observat o reducere a incidenţei OMA în sezonul rece, cu aproximativ $30 \%$.

\section{COMPLICAȚII}

Infecţia de la nivelul urechii medii se poate extinde, determinând uneori complicaţii intra şi extracraniene. Dintre complicaţiile intracraniene menţionăm abcesul cerebral, meningita acută, empiemul subdural, septicemia. Complicaţiile extracraniene sunt reprezentate de mastoidita acută (1-4/100.000 populaţie, EU, Canada, Australia, SUA, 0,3/100.000 Danemarca (7); 6,0/100.000 Israel (8); 3,8/100.000 Olanda (9)), paralizie facială, labirintită acută.

$\mathrm{Au}$ fost citate complicaţii pe termen lung precum: pierderea auzului, întârzierea dezvoltării limbajului/ vorbirii, abilităţi scăzute de socializare, perforaţia timpanului.

\section{MONITORIZARE}

Majoritatea cazurilor de OMA sunt autolimitate $(14,16)$. După rezoluţia semnelor şi simptomelor şi 
oprirea tratamentului, pacienţii vor fi reevaluaţi la 4-6 săptămâni de către medicul de medicină primară pentru a preveni persistenţa otitei medii seroase.

Pacienţii la care simptome precum durerea şi febra nu se remit în 48-72 ore de tratament vor fi reevaluaţi de medicul specialist ORL (16).

\section{BIBLIOGRAFIE}

1. Williams BG, Gouws E, Boschi-Pinto $C$ et al. Estimates of world-wide distribution of child deaths from acute respiratory infections. Lancet Infect Dis, 2002;2:25-32.

2. Kvaerner KJ, Nafstad P, Jaakkola J. Upper respiratory morbidity in preschool children: A cross-sectional study. Arch Otolaryngol Head Neck Surg, 2000; 126:1201-6.

3. Bellanti JA. Recurrent respiratory tract infections in paediatric patients. Drugs, 1997; 54 Suppl 1:1-4.

4. Agence française de securité sanitaire de produits de Robinsonsante, oct 2015. Revue de la Societé de pathologie infectieuse de langue française vol.35, nr.12, dec 2015, p.566-577.

5. Easton $\mathrm{J}$ et al. Amoxicillin/clavulanic acid - a review of its use in the management of paediatric patients with AOM. Drugs 2003; 63(3):311-340.

6. Gisselsson-Solen M. Acute otitis media in children - current treatment and prevention. Curr Infect Dis Rep. 2015 May; 17(5):476.

7. Ma'in Al Shawabkeh, Hassan Haidar, Aisha Larem, Zahraa AboulMahmood, Ali Alsaadi, Abdulsalam Alqahtani. Acute Otitis Media - An Update. Journal of Otolaryngology-ENT Research, Volume 8 - Issue 4, 2017, pg.1-6.

8. American Academy of Pediatrics: Subcommittee on Management of Acute Otitis Media. (2013). Diagnosis and management of acute otitis media. Pediatrics, Vol. 113 (5): pp.1451-1465.
Pacienţii cu simptomatologie persistentă sau cu OMA recurente vor fi reevaluaţi de un medic specialist ORL pentru o eventuală timpanocenteză. Dacă după iniţierea antibioterapiei starea pacientului nu se îmbunătăţeşte, antibioticul trebuie schimbat (16).

\section{Conflict of interest: none declared Financial support: none declared}

9. Otitis media (acute): Antimicrobial prescribing, NICE 2018.

10. Leskinen $\mathrm{K}$, Jero J. Complications of acute otitis media in children in southern Finland. Int J Pediatr Otorhinolaryngol. 2004 Mar; 68(3):31724.

11. Melissa K Van Dyke et al. Etiology of Acute Otitis Media in Children Less Than 5 Years of Age. The Pediatric Infectious Disease Journal, Volume 36, Number 3, March 2017, 271-281.

12. Jarold L Cosby, Nick Francis, Christopher C Butler. The role of evidence in the decline of antibiotic use for common respiratory infections in primary care. The Lancet Infectious Diseases, vol. 7, issue 11, pg 749-756.

13. La Saux N, Robinson JL. La prise en change de l'otite moyenne aigue chez les enfants de six mois et plus. Paediatric Child Health 2016;21 (1):45-50.

14. Children's Health Queensland Hospital and Health Service. Acute otitis media - emergency management in children 2018.

15. Pediatric Acute Otitis Media (Ear Infection) Care Process Model June 2019 Update.

16. Brenda L Natal et al. Emergent Management of Acute Otitis Media. Medscape, June 2019.

17. R. Hainăroşie, Doina Anca Pleşca, în Protocoale de diagnostic şi tratament în pediatrie, coord. Doina Anca Pleşca, Editura Amaltea, 2019, 79-88, ISBN 978-973-162-195-1. 